\title{
Sire selection and genetic improvement of dairy cattle assuming pure market competition
}

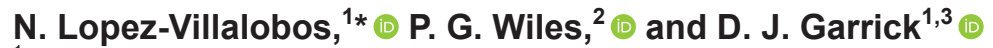 \\ ${ }^{1}$ School of Agriculture and Environment, Massey University, Private Bag 11222, Palmerston North 4442, New Zealand \\ ${ }^{2}$ Retired, 12 Jensen Street, Palmerston North 4410, New Zealand \\ ${ }^{3}$ AL Rae Centre of Genetics and Breeding, Massey University, Hamilton 3240, New Zealand
}

\begin{abstract}
Breeding companies and farmers rely on selection indices to identify sires they expect to improve production system profitability. Such indices combine estimates of genetic merit for individual traits with corresponding economic values that are fixed based on circumstances at a particular time. Perfect market competition has also been proposed as an economic basis to value alternative sires. The objective of this study was to propose an economic model and develop it for the evaluation of dairy sires. The pure competition model (PUC) was used to evaluate the relationship between a profitability index based on the PUC approach versus the traditional selection index approach for 330 dairy sires comprising Holstein-Friesians, Jerseys, and Ayrshires. The correlation between these 2 selection indices was only 0.56 , indicating that the conventional selection index did not correlate well with an index based on the PUC model. In particular, the higher ranking bulls were overvalued using the conventional selection index. Our study concluded that the use of fixed economic values is problematic for the delivery of consistent rankings in selection indices. In contrast, sire rankings based on PUC are more reliable because the sires are evaluated on the basis of efficiency gains rather than production while accounting for market prices and marginal values of dairy outputs over time.
\end{abstract}

Key words: selection index, economic value, livestock breeding

\section{INTRODUCTION}

Dairy farmers and breeders want to confidently identify and select superior sires within and across breeds. Recently, Miglior et al. (2017) reviewed the evolution of multitrait selection indices for dairy cattle breed-

Received September 11, 2019.

Accepted December 19, 2019.

*Corresponding author: N.Lopez-Villalobos@massey.ac.nz ing over the past $100 \mathrm{yr}$. Production traits that have direct monetary value (e.g., milk yield) as opposed to traits other than production (e.g., temperament) are assessed by calculating profitability via an economic model. Commonly, trait improvement is expressed in conjunction with the concept of economic values $(\mathbf{E V})$, which, if Hazel's (1943) approach is used, are defined as "the amount by which profit may be expected to increase for each unit of improvement in that trait." Mathematically, the EV implies the partial derivative of the profit function of the economic entity (e.g., farm) with respect to that trait.

The determination of EV has been controversial. Moav (1973) observed that EV depended on the viewpoint of the practitioner (e.g., breeder, dairy farmer, final consumer). Brascamp et al. (1985) tried to resolve this disparity by the introduction of "zero profit theory." Smith et al. (1986) went further and introduced enterprise rescaling to allow for the additional feed that superior stock require for their increased output. Goddard (1983) argued that EV should be determined by holding management variables constant but acknowledged that this held only for small changes and was not valid if the evaluation of the profit was conducted near a stationary point or a saddle. McArthur (1987) pointed out that most approaches to determining the profitability of trait improvement were not convincing because the models allowed profitable production to increase without limit. McArthur (1987) further redefined the concept of EV for use in a selection index. He argued that the EV of a unit change in a selected trait should include "not only the direct effect of the improvement under the set of decisions used for an unimproved animal but also the effect of the new set of decisions used to exploit the improved animal."

Melton et al. (1993) suggested that EV of traits are dependent on the level of production of that trait and potentially the levels of production of other traits. Groen et al. (1997) scrutinized the analysis by Smith et al. (1986) and observed that "interpreting this [extra profit from genetic change] as rescaling to profit of the 
herd... does not work, as this condition simply leads to zero economic values for all traits involved." Goddard (1983) voiced a related concern, stating, "If the present population mean is optimum then no genetic progress is possible and seeking economic values does not seem worthwhile." Amer and Fox (1992) challenged rescaling and linear production cost models for the assessment of profitable genetic improvement. They viewed genetic improvement as a technological change and used the neoclassical theory of the firm, or the market, as their economic perspective. Their farm model focused on long-term profit maximization accounting for adjustments for costs and revenues in a competitive external market. At the industry level, they examined EV in terms of producer surplus theory and the adjustment of market supply and demand. Irrespective of whether the approach was at the farm or the industry level, the EV were assessed using nonlinear functions. However, the authors did not detail the possible effects on varying levels of genetic gain or on herds with substantially different production characteristics, such as different breeds.

Groen et al. (1997) reviewed animal breeding methodology and saw selective breeding as the identification of animals that have the prospect of being more efficient converters of inputs (e.g., feed, labor, capital) to the outputs desired by future consumers. In addition, Groen et al. (1997) further specified that the appropriate economic perspective of the production system is competitive, with all the individual firms in equilibrium, where market prices equal the average total costs of production, and that genetic improvement is a technological development. This essentially describes perfect competition and has the consequence that the profit and an EV (for any trait), evaluated using the existing production system with its associated cost and market price structures, is zero; this was also previously noted by Goddard (1983). In addition, it is unclear how the selective improvement process disrupts this equilibrium for the purpose of sire evaluation.

This summary of the literature suggests that disagreement exists around the economic underpinnings of animal evaluation as it applies to livestock selection. Consequently, a convincing economic framework needs to be defined that binds all the participants into a common objective for the purpose of evaluating sires to more efficiently meet the needs of the overall enterprise.

\section{MATERIALS AND METHODS}

\section{Description of Pure Competition Model}

Many economic models describe the structure and behavior of players in a market. The pure competition model (PUC) of firms competing in a consumer market appears to be well suited to animal breeding. Douglas (1992) defines PUC as having the following features: (1) a large number of firms in competition, all of which are small relative to their combined output (i.e., the market), have the motivation and ability to generate profits; (2) each firm produces identical products; (3) all the firms have complete information on the best purchasing options; (4) all consumers know where to buy the cheapest products; and (5) the market demand curve for each product is downward sloping. Assumptions 3 and 4 essentially mean that the initial market is efficient in economic terms - that is, the supply and prices of goods and services in the market are optimal. Nevertheless, there is the motivation to achieve a new optimum. Essentially, the PUC model is a relaxation of the perfect competition model, where the efficiency (optimality) conditions are retained but the generation of profits is possible.

The PUC model has the key features that credibly describe an industry sector such as the dairy industry. Dairy farmers are in the pursuit of profit, although some may be unprofitable, and even the whole industry may experience overall unprofitability for periods for reasons unrelated to animal improvement (e.g., drought). In many dairy-producing countries, the largest producer seldom produces more than a few percent of the total industry output. The outputs from dairy farms are close to identical products, such as milk (comprising fat, protein, lactose minerals, and water), cull cows, and surplus of calves. The complete availability of information is one of the key drivers for the uptake of new technology and is the catalyst for innovation. Modern farming depends increasingly on the ready availability of up-to-date information. Farmers show great willingness to innovate. For genetic improvement, this means that all dairy farmers have copies of the same sire selection rankings and performance information and that they act consistently, using this information with the overall objective of increasing their own profit.

Having defined the starting point, it is also necessary to define the endpoint of the disruption that is expected to arise following a sire selection and mating decision. After an infinite period, it is assumed that PUC conditions are restored but with a new set of farm conditions, a new set of inputs and outputs, better satisfied consumers, and a new set of market prices and desirably increased profit. Consequently, we now describe the adjustment process along with a detailed production-market model to quantify the net benefit when a selected sire is mated with the herd.

Although it is daunting to realize that it will take forever for equilibrium to be restored, at least 2 factors make the problem tractable and effectively finite. Most 
helpful is the fact that only half the genetic benefit of a sire is inherited in each generation, so the curve of incremental benefits decays rapidly to the extent that further terms quickly make a negligible contribution. The proof of this is easily seen from the series $1 / 2,1 / 4$, $1 / 8,1 / 16,1 / 32,1 / 64,1 / 128$, and so on, which, it is also noted, sums to 1 .

The discounted cash flow technique also assists in making the scope of the problem finite because the profit contribution from future years in the calculation of the net present value (NPV) similarly declines rapidly, assuming that realistic discount rates are applied (e.g., $>5 \%$ ). The model assumes that all the producers in the market have full knowledge of their resources, processes, and markets, including sire merit listings, and are able to fully optimize their efforts.

\section{Sire Economic Evaluation Model}

Visscher et al. (1994) developed an economic farm model that related the quantity of feed energy consumed by a dairy herd to the energy required to produce the feasible outputs, including that for maintenance of the entire herd and growth of the herd replacements necessary to provide a stable population with realistic age structure. This model, based on ME, underpins product transformation occurring in dairy herds because for a fixed ME supply, more of one output inevitably requires a reduction in at least one other output unless there is technological or other innovation.

Importantly, the farm model describes the combinations of outputs that are feasible in an efficient production environment and the trade-offs required when selecting animals producing more of one trait and less of another trait, given the available energy resource (ultimately land devoted to growing feed). However, the markets for the outputs were treated as infinite.

The genetic merit of bulls is typically specified for a trait as the EBV or some similar measure, such as PTA, which quantifies the expected yield (e.g., milk volume) as the deviation (in liters per lactation) of the daughters from a historical herd mean. The EBV for a bull can be used, in conjunction with an appropriate herd model for a dairy system (including the raising of replacements) and a defined level of feed resource, to calculate the production function for each bull. LopezVillalobos et al. (2000) developed a detailed model of a dairy herd (including the stable generation of replacements and the elimination of culls) that was built upon the ME utilization procedure of the Visscher et al. (1994) model (see Figure 1). That model characterized the structure of the herd into annual age classes from 0 to $\geq 10$ yr. The cows that calved in early spring pro- duced milk for $270 \mathrm{~d}$ during the period of rapid pasture growth and were dried off before winter, the period of slow pasture growth. Heifers were calved at 24 mo and thereafter maintained an average calving interval of 12 mo. Artificial insemination was used in $80 \%$ of the cows and $30 \%$ of the heifers for a period of $8 \mathrm{wk}$ using semen from the selected sire. After this period, a bull was used for natural service of nonpregnant cows and heifers for a further 4 -wk period. Female progeny from non-AI bulls and infertile heifers were sold for beef within the first week after calving. Numbers of animals were updated each year using a herd-growth model according to the replacement rate imposed in the simulation. The herd's total requirements for feed, including requirements for milk production, maintenance, pregnancy, and growing of the replacements, were calculated using the formulae proposed by AFRC (1993) assuming an energy density of $10.5 \mathrm{MJ}$ of $\mathrm{ME} / \mathrm{kg}$ of pasture DM. It was assumed that $16,000 \mathrm{~kg}$ of $\mathrm{DM} /$ ha was produced by ryegrassclover pastures growing on fertile soils and that $80 \%$, or $12,000 \mathrm{~kg}$ of $\mathrm{DM} / \mathrm{ha}$, was harvested by the animals. Herd size and stocking rate (SR) were adjusted to a fixed area available for pasture production. This calculation assumes that the number of animals grazed per hectare was adjusted to meet the DM requirements, which in turn are determined by the production levels of the animals. For each of the age classes, expected phenotypic performances per cow for live weight and lactation yields of milk, fat, and protein were calculated as the sum of the values considered as the genetic base plus the genetic merit of the cows. Age adjustment factors for milk and milk component yields per cow were $0.75,0.88,0.95,1.0$, and 0.90 for lactations $1,2,3,4$ to 7 , and 8 and 9 , respectively.

Herd averages for live weight per cow and milk production per cow and per hectare were calculated each year by weighting the averages of each age class by the number of animals in that age class. Each year the model calculated the genetic merit of new progeny as the average of the genetic superiority of the selected dams and sires used as parents and each age class became 1 yr older. The starting values of the mean performance of the unimproved herd were $3,630 \mathrm{~L}$ of milk, $173.2 \mathrm{~kg}$ of fat, $127.4 \mathrm{~kg}$ of protein, and $453.5 \mathrm{~kg}$ of BW based on national averages. The total output of milk was converted into a range of standardized dairy commodities (e.g., milk powder, butter, cheese), each of which faced a downward sloping market demand curve (Figure 1) as would apply in a real market. Given any milk quantity and its composition, an optimized product mix and associated set of market prices were found annually by maximizing revenue using linear programming. We assume that the market price adjusts instantaneously to 
Farm model

\begin{tabular}{lrrrrrrr}
\hline Age (yr) & 0 & 1 & 2 & 3 & $\ldots$ & 9 & 10 \\
\hline Lactation number & & & 1 & 2 & $\ldots$ & 8 & 9 \\
Number & 976,164 & 898,071 & 800,810 & 696,144 & $\ldots$ & 188,209 & 128,848 \\
Survival & $92 \%$ & $89 \%$ & $87 \%$ & $85 \%$ & $\ldots$ & $68 \%$ & $0 \%$ \\
Estimated breeding values & 190 & 171 & 152 & 133 & $\ldots$ & 19 & 0 \\
$\quad$ Milk & 10.0 & 9.0 & 8.0 & 7.0 & $\ldots$ & 1.0 & 0.0 \\
$\quad$ Fat & 11.1 & 9.9 & 8.8 & 7.7 & $\ldots$ & 1.1 & 0.0 \\
$\quad$ Protein & 1.0 & 0.9 & 0.8 & 0.7 & $\ldots$ & 0.1 & 0.0 \\
$\quad$ Body weight & & & 0.75 & 0.95 & $\ldots$ & 0.97 & 0.92 \\
Age factor for milk production & & & & & & & \\
Production per cow & & & $2,897.3$ & $3,344.3$ & $\ldots$ & $3,618.1$ & $3,414.1$ \\
$\quad$ Milk & & & 135.0 & 155.7 & $\ldots$ & 167.8 & 158.2 \\
$\quad$ Fat & & & 105.6 & 121.5 & $\ldots$ & 129.1 & 121.4 \\
$\quad$ Protein & & & 137.6 & 158.9 & $\ldots$ & 171.9 & 162.2 \\
$\quad$ Lactose & 143.0 & 330.1 & 425.2 & 461.8 & $\ldots$ & 481.5 & 481.4 \\
Body weight & 1,197 & 2,135 & 3,854 & 4,062 & & 4,237 & 3,695 \\
\hline DM requirements & & & & & & & \\
\hline
\end{tabular}

Stocking rate 2.402 milking cows/ha

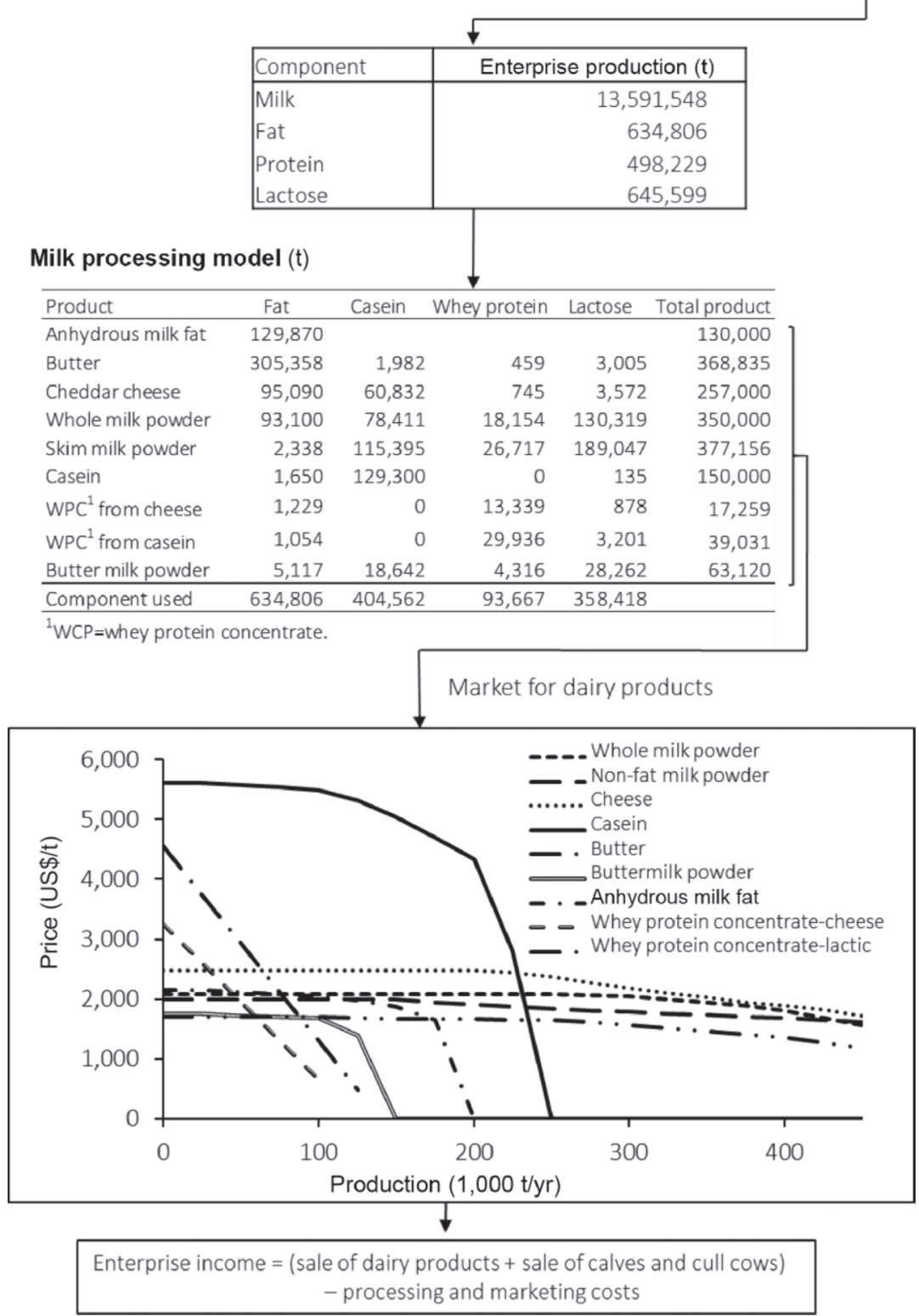

Figure 1. Representation of the farm, milk processing, and market models. 
any change in outputs. (International dairy commodity prices are established via the Global Dairy Trade auctions, which take place every 2 wk.)

Product-specific processing costs and a uniform milk harvesting cost were deducted from the product receipts. Surplus animals in the form of exiting culls and calves were given fixed prices per kilogram of BW. From these income sources, the farm income was determined. Once the model was populated with all its necessary starting data, the size of the enterprise needed to be determined that most efficiently used the available resources given the existing state of the technology. This required finding the scale at which the farm surplus (profit) was maximized, which was a result of the finite markets for the products. The scaling for maximum efficiency was achieved by invoking the linear solver and varying the herd size (number of milking cows) and successively optimizing the market prices and product mix-mass balance relationships until the maximum profit was found. Thus, for maximum profit, the national herd size of the enterprise was $3,894,905$ cows, which required 1,621,462.3 ha for an optimum SR of 2.402 milking cows/ha:

$$
\begin{aligned}
& \text { optimum SR (cows/ha) } \\
& \frac{\text { MJ of feed supply/ha per year }}{\text { average MJ expenditure/cow per year }}
\end{aligned}
$$

Having established the size of an optimal base for the enterprise and a fixed ME resource (i.e., efficient production), and given the existing technology, the focus can now turn to addressing whether for this fixed supply of ME sires can be identified that better use the resources offered by the defined farm productionprocessing-market system (enterprise) by returning an increased farm surplus (i.e., profit).

Given a selected sire, and with a set of EBV for the various production traits for that sire, and fixed pasture area (ME resource), the entire population of cows in the enterprise was mated with this sire each year (Figure 2). The optimum SR of the improved herd and the reoptimized product mix and market prices resulting from that sire selection were calculated annually. The annual enterprise profit or loss was calculated and the series was discounted to give an NPV (i.e., potential value of the selection decision). We used a discount rate of $15 \%$.

The complete model was coded in Excel (Microsoft Corp., Redmond, WA) involving some 80 linked worksheets. Premium Solver (Frontline Systems, Incline Village, NV) was used in conjunction with visual basic for applications to carry out the optimizations as required.
The model quantifies and values all relevant outputs and determines the ME required for sustained operation for each of the $19 \mathrm{yr}$ the analysis was conducted.

\section{Genetic Resources}

Estimated breeding values were obtained for 330 bulls from the national dairy cattle evaluation (www.dairynz .co.nz/animal/animal-evaluation/bull-search) for lactation yields of milk, fat, and protein and cow mature BW. The bulls consisted of 200 Holstein-Friesians (HF), 100 Jerseys, and 30 Ayrshires. Once a bull was selected as a sire, it became the established technology for mating to the herds in future years - that is, the best herd improvement option available until such time in the future when another generation of superior sires might be identified. The selected sire was mated to the herd over a period of $18 \mathrm{yr}$ (19 time periods), which encompasses more than 3 herd generations, and the series of annual values were discounted to year zero using standard discounted cash flow methodology (Figure 2).

Finally, to ensure that we are assessing the efficiency of profitable selection decisions, we obtained a profitability index for each sire by dividing the NPV (\$) of the optimized enterprise by the total kilograms of DM consumed and expressed this per $4.5 \mathrm{t}$ of DM to align it with the equivalent selection index used in New Zealand. That index, known as breeding worth, was calculated as the sum of the breeding values for live weight and lactation yields of milk, fat, and protein, each weighted by the prevailing EV $(\$ 0.796 / \mathrm{kg}$ of fat, $\$ 3.354 / \mathrm{kg}$ of protein, $-\$ 0.047 / \mathrm{kg}$ of milk, and $-\$ 0.427 /$ $\mathrm{kg}$ of BW), which were the official values used in the period of our modeling.

\section{RESULTS}

Figure 1 shows in some detail the parameters of the enterprise once it was optimally scaled. Note in particular that the total quantity of fat allocated $(634,806$ t) exactly matches the supply $(634,806 \mathrm{t})$ and that the supply of protein $(498,229 \mathrm{t})$ exactly matches the sum of the casein $(404,562 \mathrm{t})+$ whey protein $(93,667 \mathrm{t})$ produced. Thus, the solver has identified a solution up to the limit imposed by the relevant constraint of the mass balance. Only 358,418 t of lactose was allocated (used) from the supply of $645,599 \mathrm{t}$. This occurred because a considerable proportion of the lactose ended up in whey streams from cheese and casein production. We assumed that the unallocated lactose was disposed of at no cost - and no profit, which approximates practice.

Figure 3 shows the adjustment of the SR over $18 \mathrm{yr}$ resulting from selecting typical superior sires of the HF 


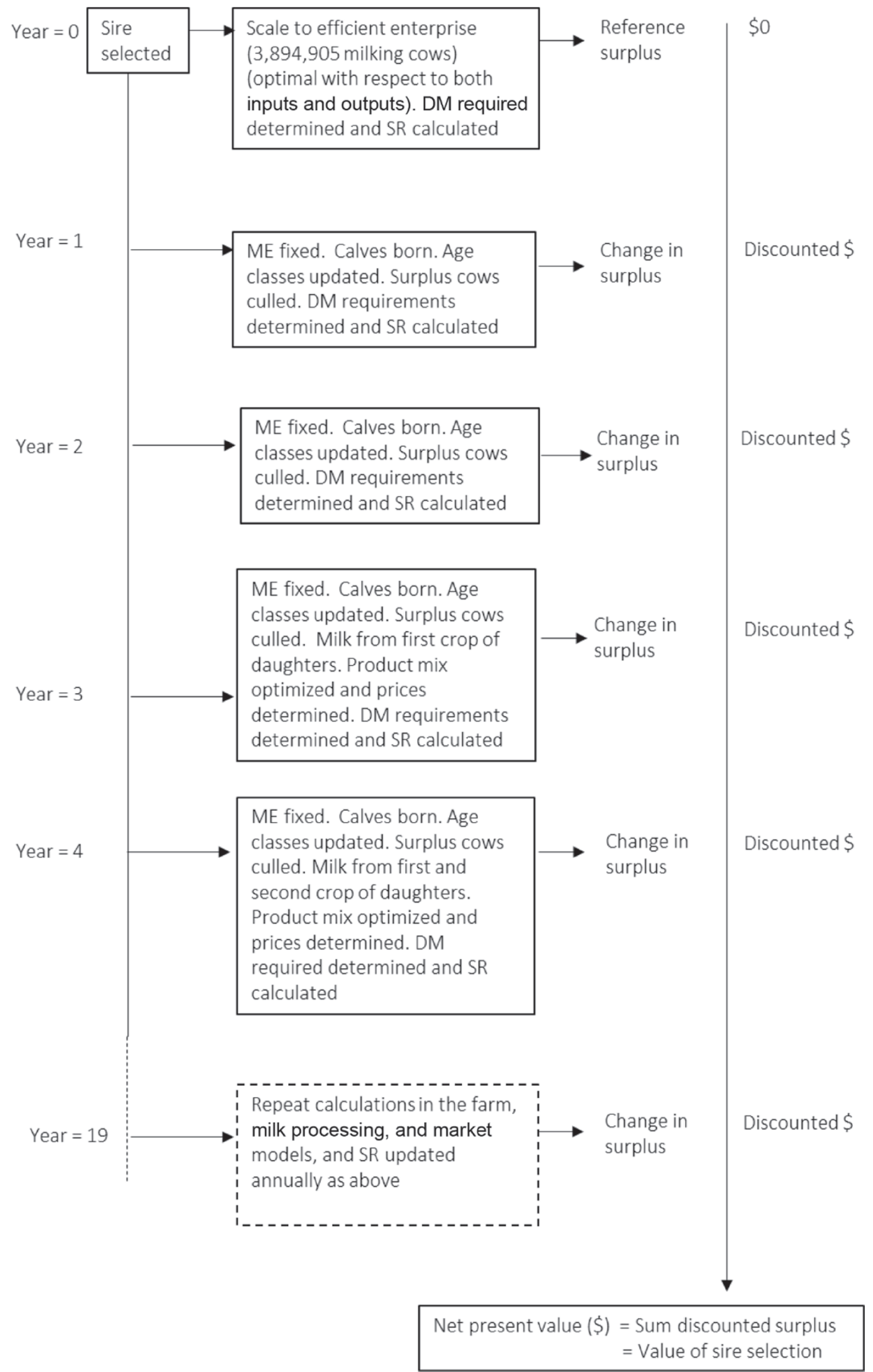

Figure 2. Calculation of the selected sire value using the pure competition model. SR = stocking rate. 


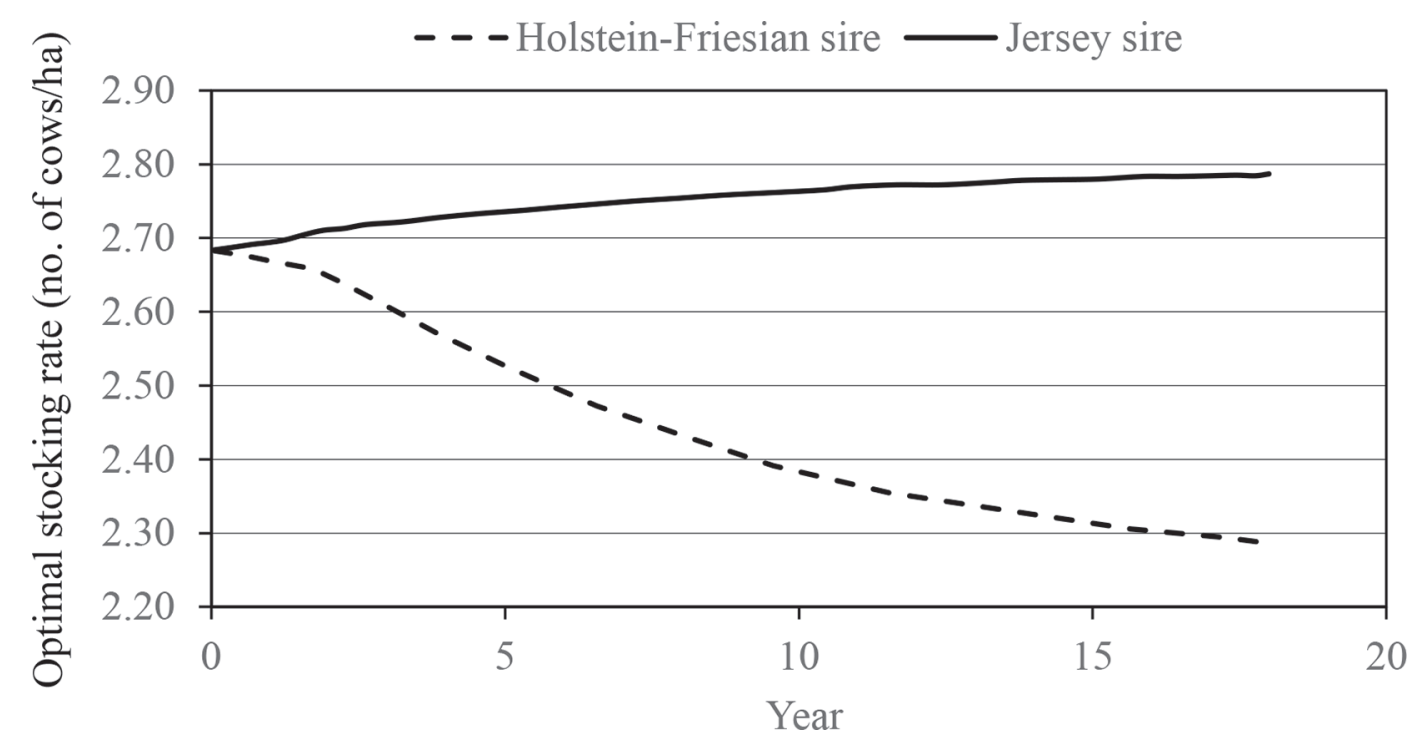

Figure 3. Stocking rate adjustment over time for herd improvement decision when cow replacements are generated by Holstein-Friesian or Jersey sires.

and Jersey breeds. In general, bulls that carry traits that result in an increase in average herd BW resulted in a decrease in SR because of the added energy consumed by their daughters for growth, outputs, and maintenance. Figure 3 demonstrates that an HF bull mated to a crossbred herd reduced the SR, whereas a Jersey bull resulted in a small increase in SR. These results were typical of the respective breeds for the 330 bulls examined.

Figure 4 shows the relationship between the expected production of fat and protein of the progeny of each bull using the PUC model. A wide range of productive values is displayed, with obvious differentiation by breed. The HF bulls tended to produce progeny with higher expected performance per cow for both protein and fat than did their Jersey counterparts.

\section{Product Transformation}

Figure 5 shows the corresponding product transformation values of these bulls in terms of productivity (in $\mathrm{kg} / \mathrm{ha}$ per year) after accounting for their eventual respective optimum SR. The change in animal and breed characterization between a yield basis $(\mathrm{kg} / \mathrm{cow}$ per lactation; Figure 4) and a productivity basis $(\mathrm{kg} /$ ha per year; Figure 5) and the grouping by breed were unexpected. Figure 5 reveals the production trade-offs between the selected outputs for a given feed resource (land). Jersey animals, which have a substantially lower BW than HF animals, devote more metabolic resources toward producing milk fat, but their protein productiv- ity is curtailed slightly. Ayrshires, with intermediate BW, fall between HF and Jerseys.

The points in Figure 5 reflect a diversity of fat and protein production efficiencies (output for a given feed input). The unimproved herd had an optimum SR of 2.402 cows/ha, yielding a point in the fat-protein product transformation space at 465 and $342.1 \mathrm{~kg} / \mathrm{ha}$ per year for fat and protein, respectively (shown in Figure 5). A possible product transformation curve (frontier) is drawn passing through the mean productivity point of the existing herd as this was the best that farmers could achieve with their existing technology and the biological substitution of fat for protein. Of particular focus are sires with prospective performances beyond the frontier. Only a limited number of the bulls are seen as offering the potential to move the product transformation frontier forward to a higher level of fat-protein production efficiency, as distinct from a higher level of production, as discerned from Figure 4.

\section{Adjustment Process for New Technology}

The general cycle of herd improvement and profitability has been described by Amer and Fox (1992), who observed that the introduction of a superior sire enables motivated and forward-thinking producers to adopt a new technology and to experience a period of economic profit until the enterprise adjusts. In their model, zero profit is restored. Bulls with the potential of higher productivity can be identified and selected from Figure 5 and mated accordingly. The enterprise 


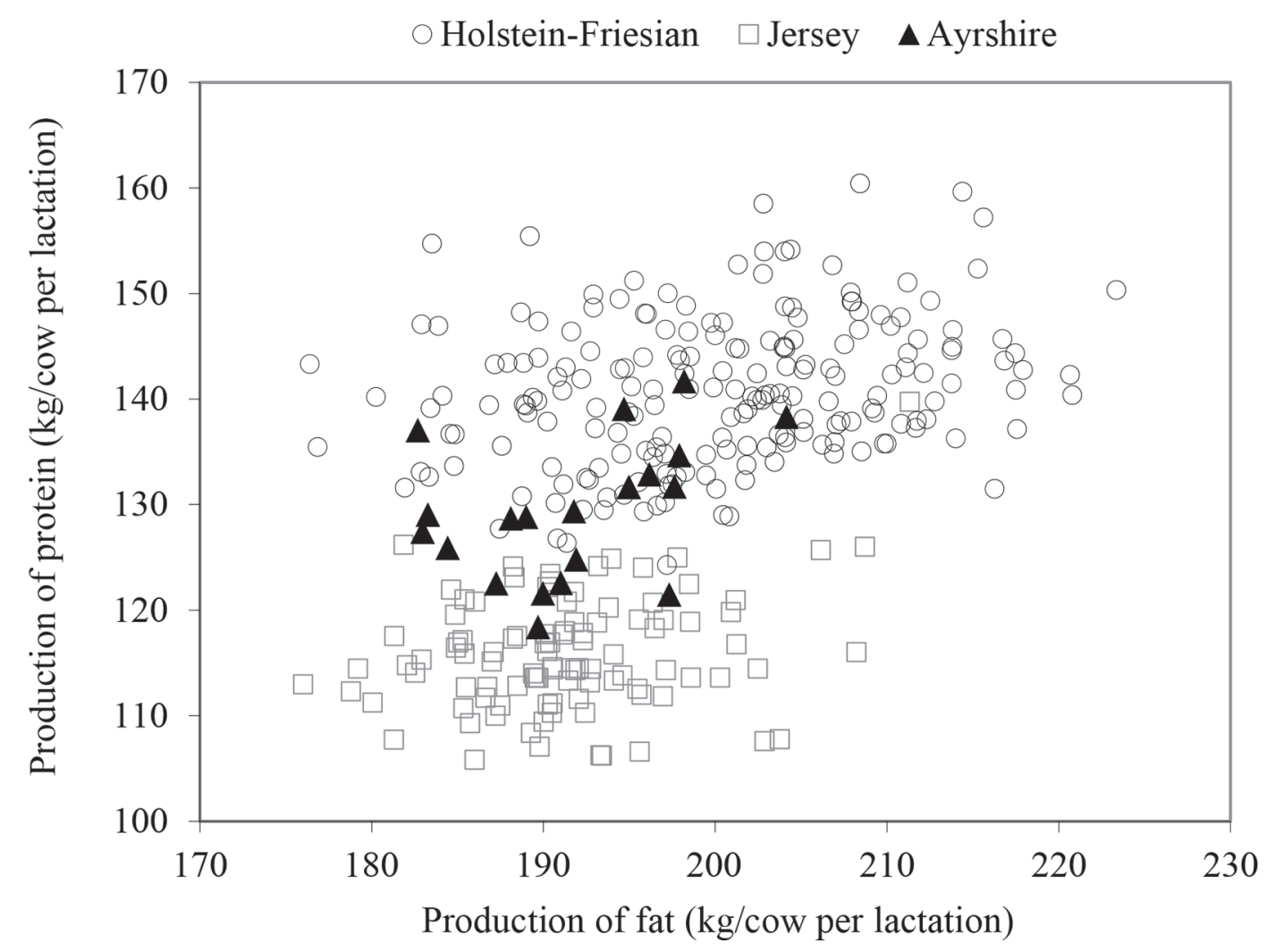

Figure 4. Bull productivity as represented in their progeny plotted as production of fat and protein per cow per lactation.

adjustment processes can now be explored by building on Amer and Fox (1992), mating the superior sires identified in Figure 4, and considering the performance of their offspring in concert with the PUC theory already outlined.

Stocking rate changes can improve farm profitability in one of 2 ways. If the SR increases, herd costs increase, but the increased income from the expanded production must outweigh the cost. If the SR decreases, then profits resulting from reduced herd costs must outweigh any reduction in farm income. These types of changes are reflected in the SR changes associated with different breeds shown in Figure 3.

\section{Comparison Between Profitability Index and Breeding Worth Index}

Within the group of bulls examined, there were a wide range of market possibilities, especially between the breeds. Figure 6 shows an impaired relationship between PUC profitability index and the breeding worth selection index of bulls of different breeds $(\mathrm{r}=0.56, P$ $<0.01$ ). In general, Jersey bulls significantly outperform $\mathrm{HF}$ once the market potential and SR factors are optimized in detail.

\section{Relationship Between Market Prices and Marginal Values of Dairy Products}

Figure 7 shows curves of market prices and the corresponding marginal values for butter and anhydrous milk fat versus annual production. Of note is the sensitivity of the marginal values at high levels of production; in extreme cases, it is possible for the marginal values to become negative.

\section{DISCUSSION}

The model proposed for sire selection in this study endorses the Amer and Fox (1992) suggestion that sire selection is essentially a technological change that aims to result in an improvement in economic efficiency. We have made several assumptions that warrant explanation. In many breeding models, the sire is mated as a one-time event to a single cow. This seems unrealistic in that farmers are collectively motivated by profit and having access to the same information to improve the production efficiency of all the animals in their herds throughout the enterprise, potentially involving thousands of farms. Similarly, in the quest for improved efficiency, a farmer would not use an improved sire 
for a single mating in year zero and revert to inferior sires (a potentially obsolete technology) in subsequent years for the pursuit of greater profit. Accordingly, we mated the selected sire annually consistently through the analysis period across the enterprise with annual optimization of the effected variables. This approach is consistent with recent advances in biotechnology that make selected genetic stock available in almost unlimited amounts. Although the result is eventually a completely inbred population, inbreeding is a distinctly different problem from the question of sire evaluation. In practice, breeding companies would generate new teams of bulls each year that might include some bulls from the team available in the previous year in addition to younger, supposedly more superior bulls. Most farmers would simultaneously select bulls each year from those new teams.

According to Cole and VanRaden (2018), there have been 2 approaches to deriving the EV of traits to be included in a selection index for the ranking of bulls and cows. The first can be called the empirical approach, which uses data from field reports to quantify incomes and expenses generated by a 1-unit increase of a trait included in the selection objective (e.g., Visscher et al., 1994; Gay et al., 2014). The second approach, which can be called the subjective approach, assigns values to the traits of the cows that breeders would like to see in the future. The empirical approach does not respond to changes in the quantity of output or to changes in milk composition. It delivers output into an infinite void as noted by McArthur (1987). The PUC model involves a direct connection with consumers who express their preferences via prices changes as production adjusts. The output commodities used in our model are pertinent to our circumstances but can be adapted to any set of market conditions (e.g., liquid milks, infant formula, fermented dairy products, cheese, and ice cream) without loss of generality.

In the initial optimal state of the PUC model, the estimation of the EV for an individual trait is especially problematic because another unit of production is not profitable given the existing technology. In contrast, the use of fixed EV allows output to be expanded profitably without limit, thereby confounding efficiency gains with production gains as voiced by McArthur (1987). In our work, once the adjustment process to the mating begins, positive EV are possible; that is, profitable possibilities may exist because new technology is being adopted. However, these fixed EV are very case specific and vary throughout the adjustment process that plays out over the years. The EV, which by definition are the partial profit for increments of extra production (the difference between marginal revenue and marginal cost), typically at year zero, are inextricably linked to the marginal revenue curves for the output commodities in play. To illustrate this sensitivity, an examination of the marginal revenue curves for the 2 key commodities containing milk fat, anhydrous milk fat (99.9\% fat) and

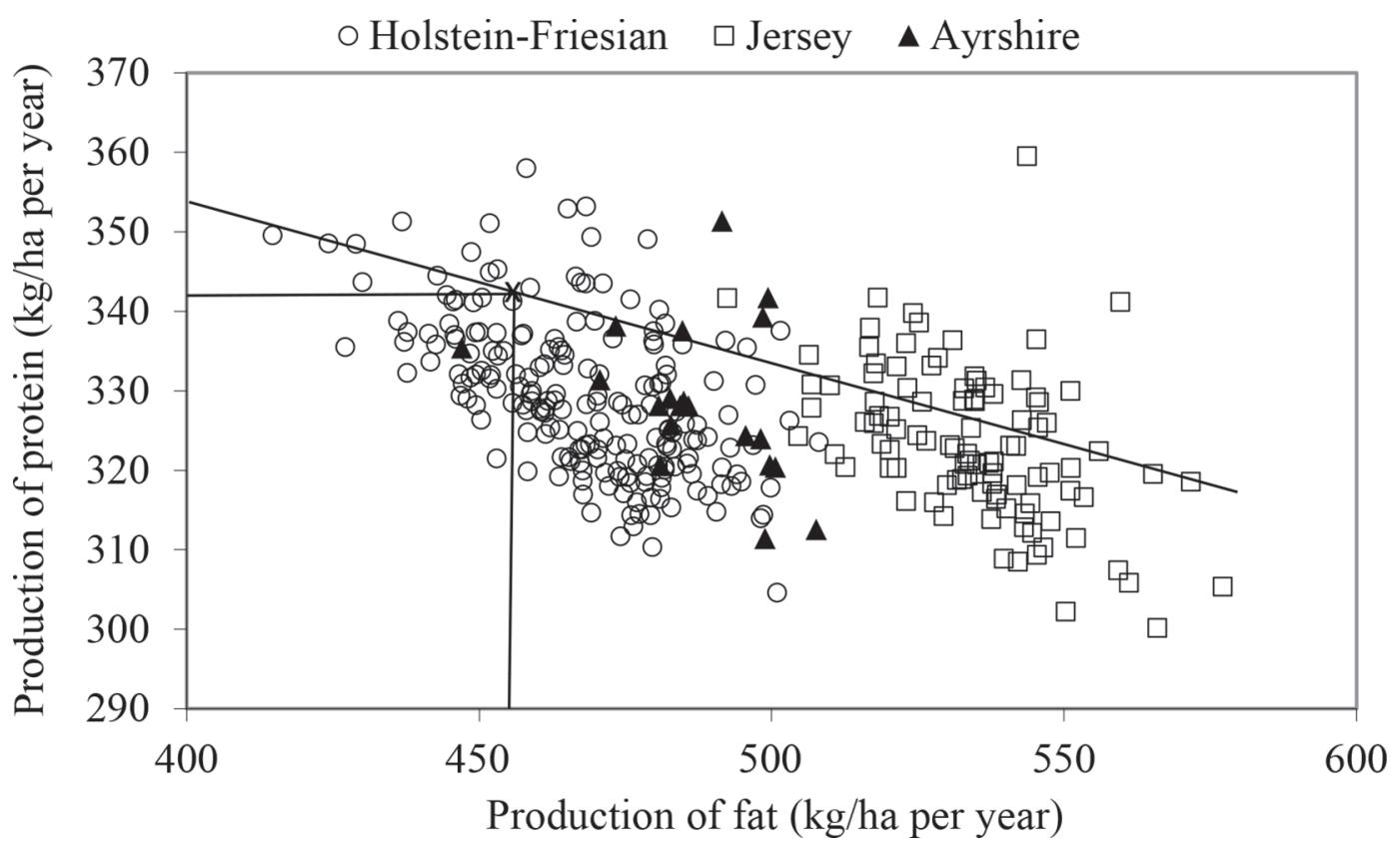

Figure 5. Product transformation of fat and protein $(\mathrm{kg} /$ ha per year) of progeny from different bulls at the eventual optimal stocking rate $(x=$ base herd average productivity). 
butter (typically $85 \%$ fat), is shown in Figure 7 . The marginal curve can be obtained for any price-quantity curve using the difference technique (Mansfield, 1991). In our initial optimal state of the enterprise, the outputs for anhydrous milk fat were approximately $130,000 \mathrm{t} / \mathrm{yr}$ and for butter were approximately 240,000 $\mathrm{t} / \mathrm{yr}$. The result is that for sire evaluations with markedly different milk compositions (especially breeds), the marginal revenues and hence EV can be expected to vary considerably, and it is inappropriate to treat them as constant or independent of the sire.

On a similar basis, these previous approaches have not adequately taken into account the effect of major changes in outputs and milk composition given that the initial base herd makeup will eventually be completely replaced by the genes of the sire. For instance, if an initial herd of substantially HF cows was mated with a Jersey sire, the eventual volume and composition of milk would change considerably, the market quantities and prices would be different, the marginal revenues would be considerably different, and the corresponding EV would change accordingly. Fixed milk component prices would not properly value the market changes, with the result that the sire would not be properly ranked, especially with regard to different breeds.

The model uses a set of potential commodities and their sloping market demand curves to value the milk output. The mix of products and their market prices is optimized in each time period to maximize the gross income. Several computational methods can be used to achieve the optimization, which is inherently nonlinear. Nonlinear solvers exist but do not guarantee a globally optimal solution. Conversely, linear solvers (e.g., simplex algorithm) do achieve globally optimal solutions but do not deal directly with nonlinear problems. We have adopted the linear solver approach and overcome the nonlinear aspect of the problem by decomposing each demand curve into a series of short, fixed price steps (production increments of 1,000 t/yr) and using integer variables and piece-wise linear optimization (Winston, 1993). Any loss of generality of the solution can be overcome (if required) by making the steps smaller (e.g., $100 \mathrm{t} / \mathrm{yr}$ ) and using greater computational effort. In addition, the stepped demand curve technique could likely take into account quota limits that result in a discontinuity in the demand curve.

The production efficiency relationships based on DM inputs that we have demonstrated could be equally well expressed on an energy input basis (MJ of ME/ha per year rather than $\mathrm{kg}$ of $\mathrm{DM} /$ ha per year) because of the direct link we have used between land area and ME intake. In recent years, New Zealand dairy farmers, following international trends, have extended the pasture feed base, with substantial levels of externally sourced

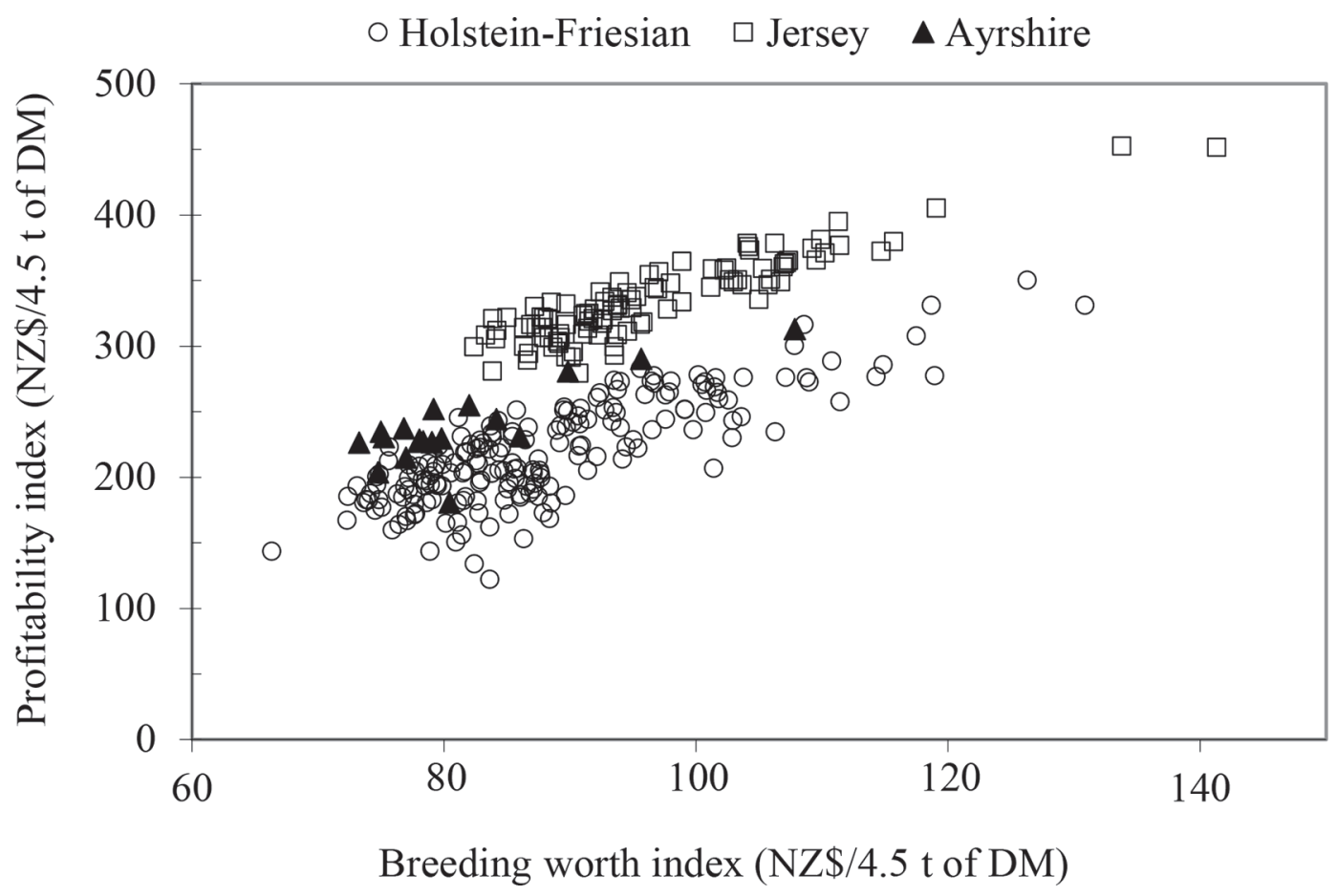

Figure 6. Relationship between profitability index and breeding worth index of bulls of different breeds. 


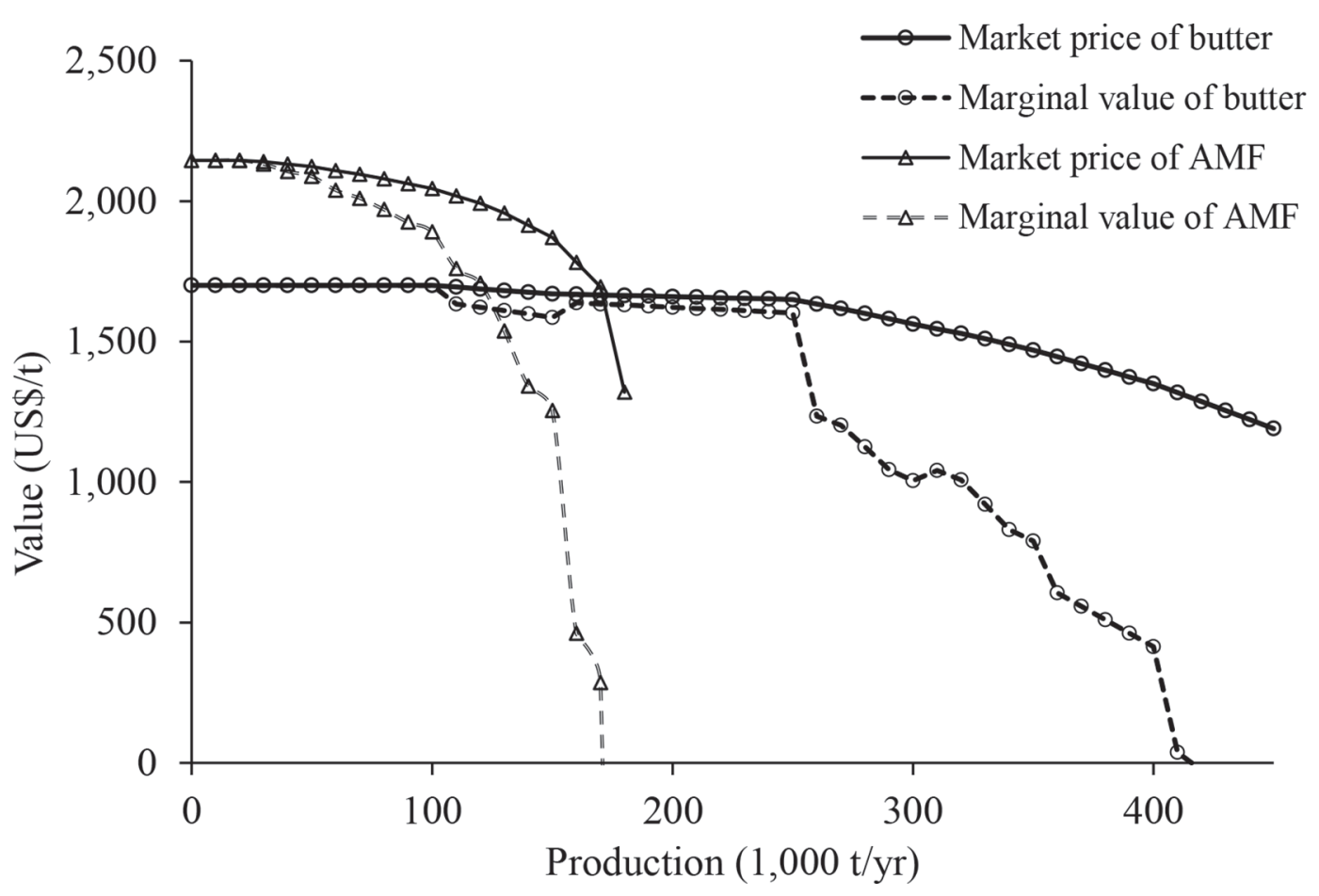

Figure 7. Curves of market prices and marginal values for butter and anhydrous milk fat (AMF) versus production curves.

feed supplements being used on some farms but not all. This makes the herd productivity gains harder to analyze because the stock performance data may be confounded with changes to the nutritional status of the herds. Considerable attention will need to be given to recent cow production data and its interpretation. In particular, some of the feed supplements contain a high lipid content, which distorts the milkfat composition and possibly its yield. By placing the focus of the model on ME rather than hectares of pasture, the scope of the model could be widened to focus on the environmental footprint of the enterprise, nonpasture feed inputs, carbon footprint (including the milk processing and supply chains of inputs and outputs), and greenhouse gas implications.

Our results confirm the observations of Moav (1973) and Melton et al. (1993) by demonstrating how levels of production influence trait profitability via the direct trade-offs between trait yields and their effect on consumer utility (satisfaction), demand, and market prices. Thus, we endorse the Groen et al. (1997) focus on efficiency of production rather than the level of production.

The gene-flow approach coupled with a detailed market response over several generations provides probably the most reliable estimate of sire economic (selection) potential. This is consistent with the observation in
McArthur (1987) that trait evaluation before implementation of the improvement program is not meaningful.

A further problem when mating a sire of high genetic merit with the herd is that the adjustment process does not affect all the traits simultaneously. Traits relating to milk characteristics adjust on a different time scale compared with BW or longevity (if included as a trait). These factors were taken into account by the multiyear evaluation process and by discounting the resultant profit series.

We have demonstrated that the conventional breeding worth index does not correlate well with an index based on enterprise efficiency ( $\$ \mathrm{NPV} / 4.5 \mathrm{t}$ of $\mathrm{DM})$. Specifically, bulls with higher BW are overvalued using the breeding worth index. This arises from a mixture

Table 1. Trends in mature cow BW $(\mathrm{kg})$ for the major breeds of New Zealand

\begin{tabular}{lccc}
\hline Year & $\begin{array}{c}\text { Holstein- } \\
\text { Friesian }\end{array}$ & $\begin{array}{c}\text { Holstein-Friesian } \\
\times \text { Jersey crossbreed }\end{array}$ & Jersey \\
\hline $2003^{1}$ & 490 & 444 & 378 \\
$2010^{2}$ & 490 & 440 & 383 \\
$2017^{3}$ & 490 & 453 & 403 \\
\hline
\end{tabular}

${ }^{1}$ Livestock Improvement Corporation (2004).

${ }^{2}$ LIC and DairyNZ (2011).

${ }^{3}$ LIC and DairyNZ (2018). 
of an inadequate assessment of the market prospects of different breeds and the effect of the necessary SR adjustments for the ME requirements. Table 1 shows the trend in cow BW in the major New Zealand breeds.

Although HF cows have maintained a steady BW, the lighter weight stock, most especially Jerseys, have shown a tendency to gradually increase in BW. To what extent this has arisen from the breeding worth index selection process and how the increase in BW affects overall production efficiency needs further research. There is concern that the breeding worth index selection process to some extent confounds the level of production with the aim of achieving higher production efficiency.

Our modeling has not considered herd longevity. It is an increasingly important trait that relates to sustainability and other farm practices. Our data did not warrant its inclusion, and Miglior et al. (2017) pointed out that there is no consistent definition for this trait, but we see no loss of generality resulting from its inclusion given suitable data. The age distribution of the herd could be adjusted over time to reflect more durable progeny, including the addition of extra age classes to capture the lengthening of the age structure of the herd. Clearly, as the mean age of the herd increases, fewer replacements are required, and the resulting ME that is no longer required to raise these replacements can be redirected to more valued outputs.

Finally, we rejected the zero profit theory and the perfect competition model. The reason is that these models define a starting point of zero profit and once the disruption has worked its way through the economy, it can be assumed that perfect competition is restored (i.e., zero profit). The problem then is to identify the intervening adjustment process. If the economy adjusts instantly (as perfect knowledge and efficiency requires), the profit always remains zero and no viable basis for sire comparison seems to exist, as others (Goddard, 1983; Groen et al., 1997) have noted previously. If, however, the economy adjusts slowly, to quantify the profit, all the responses and lags in the economy to input and output prices would need to be quantified in some way. This seems to introduce intractable complexities that go far beyond sire evaluations and make the approach unworkable.

In the review of selection indices, Miglior et al. (2017) noted the 5-fold increase in output per cow and that the selection indices have gradually broadened from production to include traits such as fertility, health, longevity, conformation, and calving workability. These authors showed that production still contributes almost half the economic emphasis of the combined set of traits in the selection index. In our study, the PUC model combines all the parties in the enterprise into a common objective of raising efficiency by linking the breeding program, the farm, and the market. Consequently, the PUC model enables the value of a sire to be calculated given a specified resource base and efficiency considerations alone.

\section{CONCLUSIONS}

The PUC model describes the important structural and behavioral features of the dairy industry for the purposes of sire evaluation. By using a PUC enterprise model, this analysis identified a population of sires that attained a higher level of production efficiency. Our approach has demonstrated the benefits of using a model of real markets as opposed to infinite markets to identify sires with the potential to increase allocative efficiency and avoid overproduction. Aspects of the perfect competition approach have been clarified in the context of dairy cattle breeding and have been rejected as unworkable. The PUC evaluation model revealed key differences between production and production efficiency when sires of different breeds were compared. We have argued that the use of fixed EV is problematic for the delivery of consistent rankings in selection indices. In contrast, sire rankings based on PUC are more reliable because the sires are evaluated on the basis of efficiency gains rather than production and account for market prices and marginal values of dairy outputs over time.

\section{ACKNOWLEDGMENTS}

The work of P. G. Wiles was funded by a contribution from the Foundation for Research, Science and Technology (Wellington, New Zealand) grant DRI X0001. The authors have stated no conflicts of interest.

\section{REFERENCES}

AFRC. 1993. Energy and Protein Requirements of Ruminants: An Advisory Manual Prepared by the AFRC Technical Committee on Responses to Nutrients. CAB International, Wallingford, UK.

Amer, P. R., and G. C. Fox. 1992. Estimation of economic weights in genetic improvement using neoclassical production theory: An alternative to rescaling. Anim. Prod. 54:341-350. https://doi.org/ 10.1017/S0003356100020791.

Brascamp, E. W., C. Smith, and D. R. Guy. 1985. Derivation of economic weights from profit functions. Anim. Prod. 40:175-180.

Cole, J. B., and P. M. VanRaden. 2018. Symposium review: Possibilities in an age of genomics: The future of selection indices. J. Dairy Sci. 101:3686-3701. https://doi.org/10.3168/jds.2017-13335.

Gay, K. D., N. J. O. Widmar, T. D. Nennich, A. P. Schinckel, J. B. Cole, and M. M. Schutz. 2014. Development of a lifetime meritbased selection index for US dairy grazing systems. J. Dairy Sci. 97:4568-4578. https://doi.org/10.3168/jds.2013-7474.

Goddard, M. E. 1983. Selection indices for non-linear profit functions. Theor. Appl. Genet. 64:339-344. https://doi.org/10.1007/ BF00274177. 
Groen, A. F., T. Steine, J.-J. Colleau, J. Pedersen, J. Pribyl, and N. Reinsch. 1997. Economic values in dairy cattle breeding, with special reference to functional traits. Report of an EAAP-working group. Livest. Prod. Sci. 49:1-21. https://doi.org/10.1016/S0301 -6226(97)00041-9.

Hazel, L. N. 1943. The genetic basis for constructing selection indexes. Genetics 28:476-490.

LIC and DairyNZ. 2011. Dairy Statistics 2011-12. LIC (Livestock Improvement Corporation) and DairyNZ, Hamilton, New Zealand.

LIC and DairyNZ. 2018. Dairy Statistics 2017-18. LIC (Livestock Improvement Corporation) and DairyNZ, Hamilton, New Zealand.

Livestock Improvement Corporation. 2004. Dairy Statistics 2003-2004. Livestock Improvement Corporation Limited, Hamilton, New Zealand.

Lopez-Villalobos, N., D. J. Garrick, C. W. Holmes, H. T. Blair, and R. J. Spelman. 2000. Profitabilities of some mating systems for dairy herds in New Zealand. J. Dairy Sci. 83:144-153. https://doi.org/ 10.3168/jds.S0022-0302(00)74865-X.

Mansfield, E. 1991. Microeconomics. 7th ed. Norton, New York, NY.

McArthur, A. T. G. 1987. Weighting breeding objectives-An economic approach. Pages 179-187 in Proc. 6th Conf. Aust. Assoc. Anim. Breed. Genet. Univ. West. Aus., Perth, WA, Aust. Accessed Feb. 14, 2020. http://www.aaabg.org/proceedings/1987/ab87031.pdf.

Melton, B. E., R. L. Willham, and E. O. Heady. 1993. A note on the estimation of economic values for selection indices: A response. Anim. Prod. 59:455-459.
Miglior, F., A. Fleming, F. Malchiodi, L. F. Brito, P. Martin, and C. F. Baes. 2017. A 100-year review: Identification and genetic selection of economically important traits in dairy cattle. J. Dairy Sci. 100:10251-10271. https://doi.org/10.3168/jds.2017-12968.

Moav, R. 1973. Economic evaluation of differences. Pages 319-352 in Agricultural Genetics: Selected Topics. Wiley, New York, NY.

Smith, C., J. W. James, and E. W. Brascamp. 1986. On the derivation of economic weights in livestock improvement. Anim. Prod. 43:545-551. https://doi.org/10.1017/S0003356100002750.

Visscher, P. M., P. J. Bowman, and M. E. Goddard. 1994. Breeding objectives for pasture based dairy production. Livest. Prod. Sci. 40:123-137. https://doi.org/10.1016/0301-6226(94)90042-6.

Winston, W. L. 1993. Operations Research: Applications and Algorithms. 3rd ed. Duxbury Press, Belmont, CA.

\section{ORCIDS}

N. Lopez-Villalobos 주 https://orcid.org/0000-0001-6611-907X

P. G. Wiles ๑ https://orcid.org/0000-0002-9312-1906

D. J. Garrick 나 https://orcid.org/0000-0001-8640-5372 